\title{
Teacher's Profile in the Context of Changing in the School Organization
}

\author{
Florentina Ciulei (Ionescu) \\ ciuleiflorentina@gmail.com \\ Angela Morlovea \\ angiboros@yahoo.com \\ Valahia University of Targoviste, Romania
}

In this paper we propose a mapping of the profile of the teacher staff within the current school organization, a summary of the roles they undertake to fulfill in the exercise of the teaching profession and the establishment of a framework of competences necessary for the teacher in the Romanian pre-university education system. Coordinates of the teacher profile can only be determined by reference to the organization it is part of, in close connection with the coherent strategic set of European and national educational policies.

Key words: teacher, educational standard, school organization, change, teaching career, professional competence

JEL Classification: I21

\section{The school organization - context of shaping the profile of the teacher}

In defining the concept of an organization, theories converge, so the organization is defined as:

- "an ensemble of persons pursuing a determined, identical or complementary purpose, constituted in structures, functional according to rules which aim to adjust the relations of belonging elements" (Neveanu, P.P., 1978, p. 270).

- "a world of exchanges and conflicts, a tool of cooperation between conflicting interests, a decision-making arena, a context in which they encounter, confront and adapt rationalities and multiple behaviors, possibly contradictory or just a gaming structure of formal and informal characteristics and rules, channel and regulate simultaneously the power strategies of the different participants, being the stake and the product of the latter "(Friedberg, E., 1992, pp. 408-409).

- "an orderly and hierarchical human ensemble, for cooperation and coordination their members for certain purposes" (Sociology Dictionary, 1996, p. 341).

"The organization is defined as a system of activities structured around explicitly formulated goals (goals, objectives), which trains a large number of individuals having welldefined statuses and roles within a differentiated structure with functions of leadership and coordination of activities "(E. Paun).

Professor E. Păun touches the organizational features through: organizational structure, organizational control, organizational behavior (purpose, culture, climate, ethos, efficiency) and organizational change (flexibility, staff development). The capacity for change is a significant indicator for the strength and "health" of the organization (Paun, E, 1999, p. 7).

The common points that can be extracted from the definitions given to organizations concern:

- people who interact for a common purpose;

- interactions ordered in a particular structure;

- the structure that describes the roles, relationships, activities, objectives, authority hierarchy, the specific responsibilities of the organization with levels of centralization / decentralization authority, bureaucracy; 
- organizational behavior in culture, climate, ethos;

- organizational change for both the organization and its staff.

All types of school organizations (state and private institutions based on different educational principles, such as classical schools and those included in the "new school" category of different pre-university grades: kindergartens, primary and secondary schools, universities) have more points common than differences, it can be said that psychosocial theories about these can be reunited in a more general theory that allows the analysis of a school organization.

The school organization defines conceptually the basic unit of the education system, designed as an "institutional factor of education", specialized in the realization of the educational process according to the general and specific pedagogical objectives established at the level of the educational policy. (https://www.scribd.com/document/377993061/Ce-Este-o-OrganizatieScolara). This can not be achieved without the involvement of human resources in the educational sphere.

Areas of research that focus on investigating different aspects of the teaching profession are relatively distinct. In pedagogy, deontology focuses on the responsibilities and rights of teachers with respect to their pupils, while pedagogy involves the characteristics of teachers determined by their roles (Rosić, 2011, p.142-149), the complexity of the work carried out by the framework didactic approach to the assumption of a whole series of roles determined by the specificity of its activity.

The teaching profession is associated with a few fundamental categories of roles accepted in most of the teacher training systems: design, management and organization of learning activities, psycho-educational counseling, classroom management, communication with students, parents and colleagues, professional development lifelong learning, participation in improving the educational process and school innovations, providing educational services to the community, etc.

In the specialty literature, it is appreciated that the didactic profession can not be confined to the simple source of knowledge. However, the leading role of the teacher in teaching remains one of the basic coordinates of his mission, Woolfolk Hoy A. Educational Psychology Specialist mentions the following teaching profession:

- making decisions about what is happening in the educational process;

- triggering and maintaining students' interest, curiosity and desire for learning;

- leadership of the group of students; guides persuasively students, advises them and observes their behavior; represents a positive pattern of personality and behavior for its pupils; understands, reflects on class events, studies the psycho-pedagogical phenomena they face.

The teacher has a multitude of roles in a close relationship with his personality and in order to achieve the objectives provided in the school documents.

Regarding the diversity of roles the teacher can exercise, the following can be distinguished:

- The teacher, as an expert in the teaching-learning act. he can make decisions about everything that happens in the education process.

- The teacher as a motivating agent triggers and maintains their interest, curiosity and desire for learning activity

- The teacher, as a leader, leads a group of students, exercising their power over the main phenomena that occur here. He is a friend and confidant of the pupils, a substitute for parents, an object of affection, and support in improving anxiety.

- The teacher, as a counselor, is a sensitive observer of the students behavior, a persuasive mentor and a counselor.

- The teacher as a model: through his whole personality, through his actions, his behavior is a positive example for the students. 
- The teacher, as a reflective professional, always strives to understand and reflect on the new classroom events, to study and analyze the psycho-pedagogical phenomena they face.

- The teacher, as a manager, supervises the whole classroom activity, ensures consensus with other teachers, parents and other factors. (Woolfolk Hoy A., 2010, pp. 257-270).

By working in the school, the teacher does not cease to be an educator outside of the school, pursuing, of course, specific objectives and using appropriate means and forms. Only to the extent that the teacher continues his / her mission outside the professional framework offered by the school can be considered a teacher of his people.

Complementary to the didactic activity, the curriculum of the didactic framework also carries out extra-curricular or cultural-educational activity. The two sides of his activity, both school and extra-curricular, are not only supposed to, but also complete and complement each other, imparting to this profession an increased role in the overall progress of our homeland.

The social aspect of this profession is to participate in the social-cultural events of the time it lives and the people it is part of. In this hypostasis, the teacher appears to us as a social pedagogue, animated by the concern to raise the degree of culture and its nation.

The role of the teacher can also be analyzed from the perspective of the teacher-student relationship. Taking into account the values of contemporary society (freedom, responsibility, tolerance, cooperation), the author emphasizes the idea that a new approach to the teacherstudent relationship is necessary:

- the assumption by the teacher and pupils of a common moral responsibility within the educational relationship, leading to an affective and effective engagement in the educational process;

- the mutual recognition of "the right to be different" and the valorisation of each individual human being, no matter how and how different; trust in the possibilities of every human being to progress;

- recognizing that all pupils and teachers are social partners with complementary, but shared responsibilities; considering the school as a cultural building environment;

- abandoning the principle of a "single best way" and becoming aware of the fact that most social and human issues have more equivalent solutions;

- promoting authenticity and sincerity - to be yourself is more important than to be right.

Assuming a multitude of roles, the teacher must realize that their exercise depends on the personality they are shaping. In this sense, a particular role in the exercise of this profession has certain components of the personality: professional culture, attitudinal and aptitude qualities. In fact, for certain knowledge to be passed on from one person to another and accepted, there must always be an emotional exchange of trust and responsiveness from one side to the other.

The current concerns in the field of education raise new and important issues regarding the roles played by teachers in the teaching profession, gravitating around four fundamental coordinates: learning to learn, learning to learn, learning to live with others, and learning to be . Depending on this perspective, but also on the implications of globalization on individuals, the issues of the contemporary world, educators in education follow to perform new roles.

In Romania, the methodology for applying the new national curriculum requires teachers to create learning situations appropriate to the intended objectives, referring to the nature of the topic of the lesson and the particularities of the class or group of pupils. The idea is not new in pedagogy, but this role attributed to the teaching staff is more recent, and today it is formulated explicitly and specified in the didactic design documents. Obviously, the more learning situations will be better chosen or imagined by the teacher, the more interesting and effective in learning will be the training.

Another new role created by the current methodological changes could be that of a meditator in the process of knowledge or counseling, alongside the traditional role of information transmitter, which is not discarded, but whose share is, visibly, decreasing in education modern, 
competence-centered. Also, the teacher is today a real agent of change, preparing its students in this perspective, which is becoming more and more in a dimension of contemporary man.

At present, the teacher is called upon to get involved in educational policy decisions at different levels, as well as in the complex, difficult process of insertion of the new conditions. A number of new roles also derive from the implications of continuing education on school curricula. They tend to integrate both horizontally and vertically, focus on values, attitudes and motivation, cultivate independence, ownership, flexibility, and facilitate people's development.

\section{Presentation of the professional standard of the teacher}

\subsection{European teacher's profile}

In the countries of the European Union, either a proficiency profile was defined, as in Germany and Denmark, or formal elements of the teacher were formalized in the form of professional standards (England - 2012, France - 2013), Qualification standards (Ireland - 2013, Sweden), requirements, curricular areas, minimum learning outcomes for initial training programs (Poland, Ireland, Spain, Austria) or country priorities, objectives and / or recommendations ).

Mapping the profile of teachers in European countries involves:

$\checkmark$ guiding initial and / or continuous training programs (Finland);

$\checkmark$ governance of universities and training institutes (Poland, Estonia,Austria,Spain)

$\checkmark$ assessment of initial and / or continuous training providers (England);

$\checkmark$ certification or qualification of teachers (Ireland, Sweden) or teacher performance and professional development (Poland) assessment. (Eurydice, 2017)

In educational policies, there are two approaches to defining and using teacher competency standards, bureaucratic and other formative, in line with their educational policies towards centralization/decentralization, respectively control / trust:

- In the bureaucratic approach, the standards are prescriptive, detailed and used to measure, compare and control individual behavior.

- In the formative approach, the standards are broadly or principally defined, they value the teacher's discernment and are used as reflection and guidance tools for the teacher or group (professional category, school, etc.). (European Commission, 2013).

The educational policies of Estonia and Finland, two countries with some of the best results in PISA 2015, and Poland, a country with a history and geographical extent comparable to that of Romania, are illustrative from this point of view in Table no. 1.

In Estonia, initial training, insertion, continuous training and career development of teachers are regulated by two normative documents: Framework Requirements for Teacher Training (2000) and Professional Standards for Teachers in General Education (2013), Special and Vocational (2014). Professional standards include mandatory and optional skills, and activity indicators organized on four levels of performance. (Eurydice, 2017)

The Ministry of Science and Higher Education in Poland has established in 2012 National Standards describing the study modules for initial teacher education (general description, content and practice objectives) and learning outcomes (social knowledge, skills and competences). In addition, Poland has a complex teacher evaluation system (focusing on the quality of education services) and a teacher evaluation system (as a basis for promotion). (Eurydice, 2017)

Finland did not standardize a teacher profile at national level. Teacher training follows general principles / country priorities. In this respect, Finland organized in 2007 a Consultative Council for the Development of Vocational Training Staff and in 2017 the Teacher Training Forum. These forums have the role of formulating priorities, recommendations and supporting teacher training. (Eurydice, 2017). 
"Dunarea de Jos" University of Galati, Romania - Faculty of Economics and Business Administration

\begin{tabular}{|c|c|c|}
\hline Estonia & Poland & Finland \\
\hline $\begin{array}{c}\text { Decentralization, } \\
\text { Control, } \\
\text { Professionalization } \\
\end{array}$ & $\begin{array}{c}\text { Decentralization, } \\
\text { Control, } \\
\text { Professionalization }\end{array}$ & $\begin{array}{c}\text { Decentralization } \\
\text { Trust, } \\
\text { Professionalization } \\
\end{array}$ \\
\hline $\begin{array}{l}\text { According to the Professional } \\
\text { Standards for Teachers in General } \\
\text { Education (2013): } \\
6 \text { required skills: } \\
\text { - Planning of learning and } \\
\text { teaching; } \\
\text { - Designing learning environments; } \\
\text { - Supporting learning and } \\
\text { development; } \\
\text { - Reflection and professional } \\
\text { development; } \\
\text { - Counseling and mentoring; } \\
\text { - Development, creation and } \\
\text { research. } \\
2 \text { optional competencies } \\
\text { - Management; } \\
\text { - Mentoring and teacher training. }\end{array}$ & $\begin{array}{l}\text { According to National Standards (2012), } \\
\text { at the end of the initial training, the } \\
\text { teacher: } \\
\text { - Has the knowledge of psychology and } \\
\text { pedagogy necessary to understand } \\
\text { processes of development, socialization, } \\
\text { education, teaching and learning; } \\
\text { - Know methods of facilitating learning } \\
\text { and have experience of putting them } \\
\text { into practice; } \\
\text { - Has the necessary skills for teaching, } \\
\text { accomplishment } \\
\text { other school-related tasks, including } \\
\text { curricular adaptation } \\
\text { to students' needs; } \\
\text { - Has the ability to learn and develop } \\
\text { their own pedagogical techniques and } \\
\text { methods, using modern methods of } \\
\text { searching, organizing and processing } \\
\text { information and materials; } \\
\text { - Communicates successfully using } \\
\text { various communication techniques with } \\
\text { people involved in learning processes } \\
\text { and other stakeholders; } \\
\text { - Demonstrate ethics, empathy, } \\
\text { openness, ability to reflects, pro-social } \\
\text { attitudes and sense of responsibility }\end{array}$ & $\begin{array}{l}\text { According to the Ministry of } \\
\text { Education and Culture website, } \\
\text { Finnish teachers believe in: } \\
\text { - Equity and encouragement; } \\
\text { - Individual support; } \\
\text { - Strengthen students' thinking } \\
\text { abilities; } \\
\text { - Developing self-confidence and } \\
\text { student tolerance. } \\
\text { - Investing in teacher training is } \\
\text { the best way to meet the } \\
\text { challenges of the educational } \\
\text { environment; the teacher's } \\
\text { - The high trust in the teacher. } \\
\text { work is kept the best students } \\
\text { want to become teachers. }\end{array}$ \\
\hline
\end{tabular}

Table no. 1 - Comparative excerpts from normative documents / publications on the profile of teachers Estonia, Poland and Finland (Eurydice, 2017)

\subsection{Elements of the teacher's profile in the form of professional standards in the Romanian educational space}

In 1999 Romania published the occupational standard describing the competencies required for the pre-university teacher, as well as the criteria for their evaluation (evaluation).

The occupational standard is managed by the National Authority for Qualifications (NAQ). However, the normative act governing the accreditation and evaluation of teacher training and certification programs is the Framework Methodology for organizing psychopedagogical training programs for the certification of competences for the teaching profession, issued by M.E.N.C.S. by Order no. 5745 / 13.09.2012. Specialists found that this latter order is not correlated with the 1999 Occupational Standard, it does not describe the endpoints of psycho-pedagogical training programs, but the curriculum and the conditions for certification of competences for the teaching profession (http://dialoguriedu.cpedu.ro/wpcontent/uploads/2017/08/Document-Pozitie-Profilul-de-competente-al-profesorului.pdf).

In July 2016, by Order of the ME no. 4476 / 06.07.2016 approved the professional standards of continuous training for the didactic teaching position of teacher in pre-university education, by pre-school, primary, gymnasium and lyceum levels, and by stages of professional development in didactic career. Thus, programmatic documents, which should have supported the teacher training efforts, are incomplete, incomplete or publicly unaffected, which negatively influences the collaboration of the parties involved and efforts to improve the teacher training programs. 
The new ARACIP (2017) external quality assessment standards provide for the evaluation of the activity of "regular monitoring and evaluation of staff in line with current legislation" (ARACIP Standards, 2017). However, this standard puts managers in a problematic situation because Romania lacks the legislative context to which it should have been reporting.

The OECD report, published with the support of UNICEF in 2017, reported this and signals that in the absence of common teaching standards in different contexts, teacher evaluation is made using different evaluation criteria and tools that do not cover all the necessary skills " for an effective teaching activity ". OECD experts, in line with economic rationality in education, have recommended the development of common professional teaching standards that would favor the "orientation of evaluations and all teaching policies towards key competences for effective teaching and implementation of the new curriculum" (OECD, 2017).

The pre-university educational space in Romania sets the professional standards of the teaching staff, delimiting the competences, but also the standards derived from them, in several categories, according to figure no. 1.

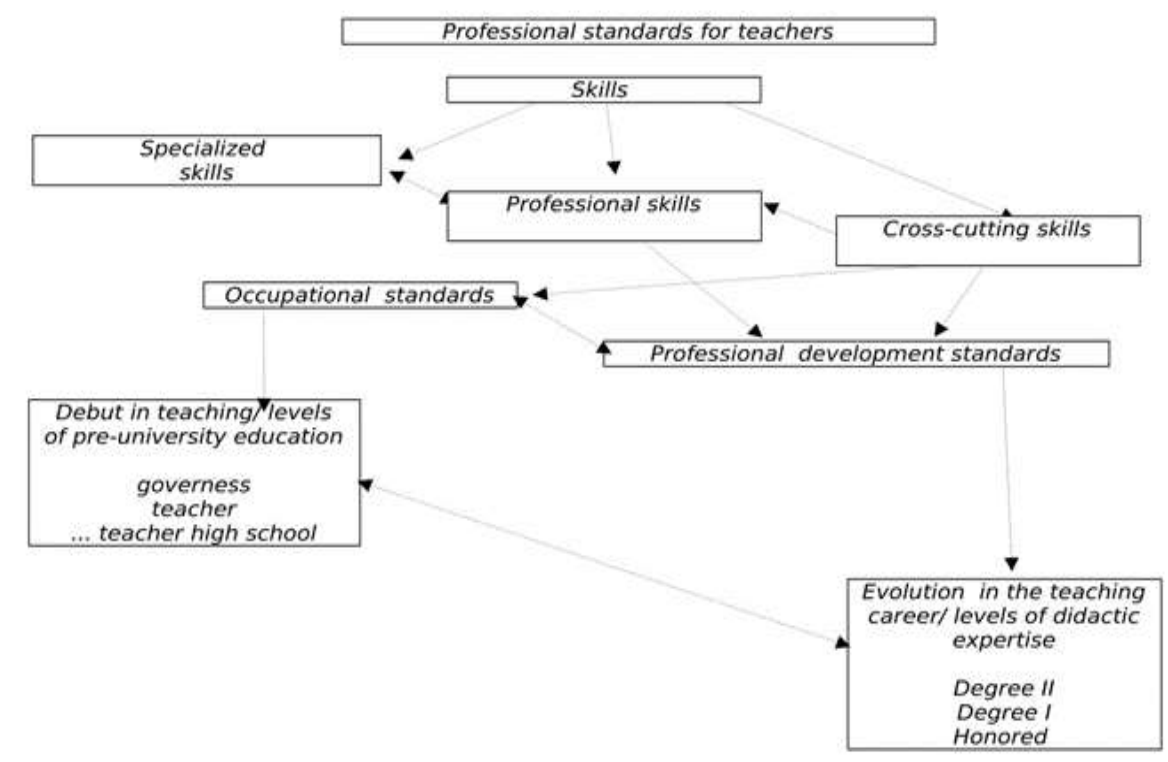

Figure no. 1: Teacher competences categories

Annex 2 to ME no. 4476 / 06.07.2016- Professional Standard of Continuous Training for Teaching

Teaching Teacher for Pre-university Education (https://www.edu.ro/formare-continua)

\subsection{Teacher's profile... from competences to teaching career}

The teaching staff has an extremely important mission in that it ensures the formation and training of the younger personality and their professional training within the school organizations, in close connection with socio-professional, moral and civic activity.

A definition of didactic competence starts with the establishment of the general sense of competence. A term widely used by different people in different contexts, competence is defined in a variety of ways.

Specialists up to the 1950s to 1960 understood by competence - a combination of knowledge, skills and practical knowledge used to improve performance as well as the status / quality of being properly qualified and capable of performing a particular role.

The Occupational Competence Movement, initiated by David McClelland in the 1960s, sought to deviate from traditional approaches to describe competency in terms of knowledge, skills and attitudes, and instead to focus on those values, features and specific motivations (relative features sustainable people).

The term "competence" first appeared in an article written by Craig C. Lundberg in 1970 entitled Planning the Executive Development Program, then in David McClelland's 1973 Treaty 
entitled Competence Testing rather than Intelligence. The term was popularized by Richard Boyatzis and many others (Nessipbayeva O., 2012, p. 149)

Current education is skill-based and includes the knowledge, skills and values that a firsttime teacher has to demonstrate to successfully complete an initial training program (Houstan, 1987). During the teaching career, these skills are enriched, filtered, polished, evolving, professional expertise, fulfillment.

The Ministry of National Education is a promoter of this competence-based education concept, organizing various debates, round tables on this topic. In the "Dialogues on Education" debate held on June 28 2017, 78 people participated in a brainstorming exercise and attended 60 teachers, representatives of some school institutions, nonprofit organizations or companies, in which they expressed opinions on the knowledge, skills, attitudes, aspirations of the 21st Century teacher.

In table no. 2 summarizes the result of the exercise by listing the competencies identified by the participants.

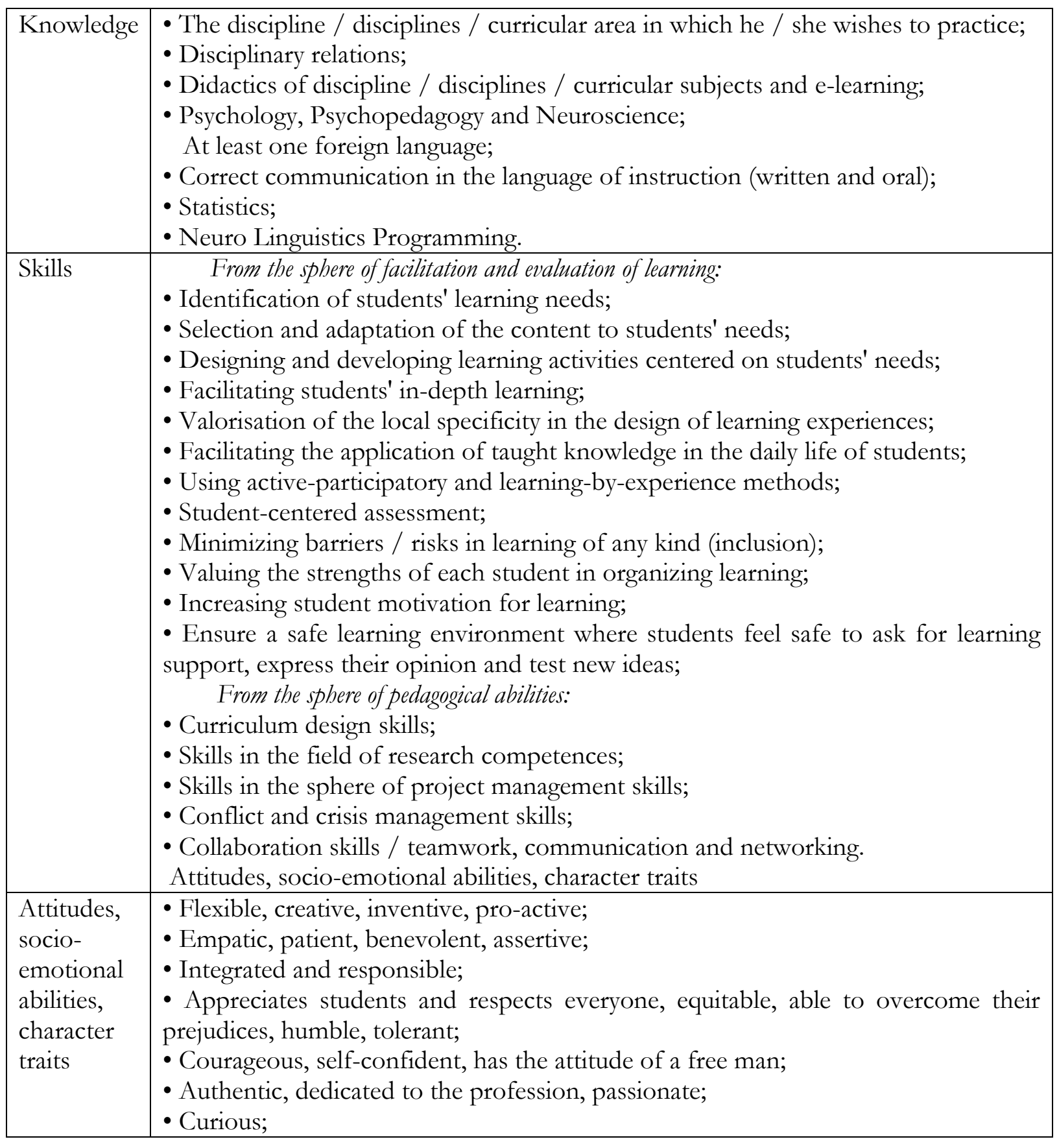




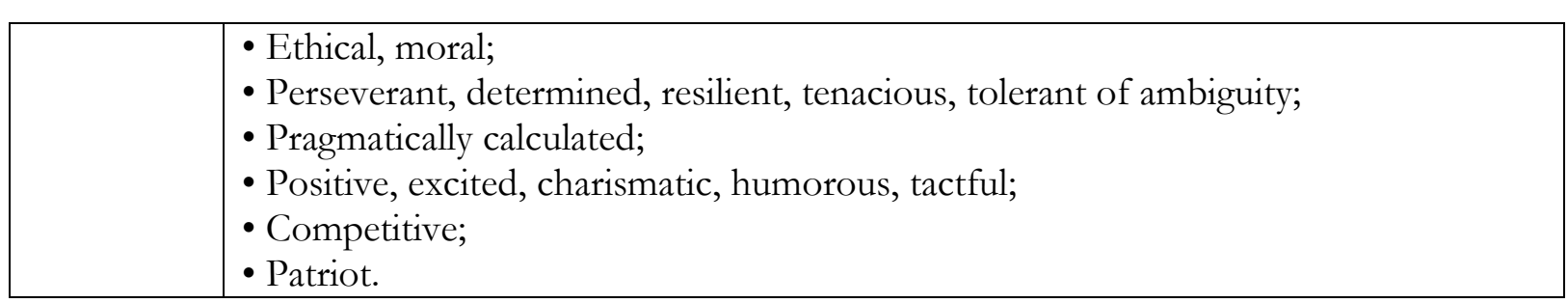

Table no. 2 - Teacher's profile - adapted after http://dialoguriedu.cpedu.ro/wpcontent/uploads/2017/08/Document-Pozitie-Profilul-de-competente-al-profesorului.pdf

Also in the same debate, the participants stressed that the main aspirations of the teacher should be directed to continuous learning and self-fulfillment, but also professional fulfillment. At the same time, the Romanian Academy publishes a project containing the principles and vision of a strategy for education designed to establish the "portrait" of the school to Romania in 2035, called Romania's Development Strategy for the next 20 years.

Thus, the specialists redefine the education and training system in the context imposed by the paradigm: "Educated Romania - RE-TOP 10", which implies the establishment of objectives, programs, targets, indicators and educational policies which, through implementation, will ensure the requirements imposed on a Efficient, competitive European Education System (SNE). The major goal of SNE's restructuring is to raise citizens' level of education in the spirit of respect for work, honesty, fairness, love for peers, civic democracy values, creative and innovative professionals, and the knowledge society.

One of the general strategic objectives proposed in Volume I of the Strategy is redefining the teacher profession, its noble role in society, and providing the formal framework for the initial and continuing training of future generations of educators, teachers, professors and university professors. (Romanian Academy, Ion Acad. Valentin Vlad, Romania's Development Strategy for the Next 20 Years, 2015, pp. 11-30).

\section{Conclusions}

A profound transformation of education at conceptual, systemic and procedural level can not be undertaken professionally and democratically without the support of a coherent strategic ensemble, of public policy direction transformed into a project of prioritized educational policies, programs and projects.

One of the most important aspects of the educational process is related to the quality of the human resource that ensures its management. Teacher John Hattie, in his Visible Learning book on the factors that make the most of the learning process, advocated that the role of teachers and the quality of teaching are at the forefront. Paraphrasing, the quality of an education system will never be superior to that of class teachers.

Starting from these assumptions, but also from the fact that teachers themselves need to be in a continuous process of learning to meet the challenges of the 21 st century, it is necessary to have a certain type of teacher with a framework profile, interested and open to a permanent professional and personal development, focused on the improvement of professional competencies, which have been developed for the development of children, pupils and other beneficiaries of the educational process.

\section{References:}

1. Friedberg, E., Organizatia, in XXX (coord. R. Bourdon), Tratat de sociologie (traducere din limba franceză), Ed. Humanitas, Bucuresti, 1992, pag. 408-409.

2. Nessipbayeva O., Bulgarian Comparative Education Society, Paper presented at the Annual Meeting of the Bulgarian Comparative Education Society, 2012, pag. 149

3. Neveanu, P.P., Dictionar de psibologie, Ed. Albatros, Bucuresti, 1978, pag. 270.

3. Păun, E., Școala - abordare sociopedagogică, Ed. Polirom, Iași, 1999, pag. 7. 
4. Rosić, V., Deontologija uaritelja - temelj pedagoške etike [Teacher's deontology - the basis of the pedagogical ethics]. [In Croatian]. Informatologia, 44(2), 2011, pag. 142-149.

5. Woolfolk Hoy A., (2010), Educational Psychology in Teacher Education, Volume 35, 2000 - Issue 4, p. 257-270

6. Teacher competence in bigher education. The chapter from book. Retrieved in February 2012 from bttp:// wnw.egyankosh.ac.in/bitstream/123456789/24676/1/Unit6.pdf, accessed 04.04.2019, 9.30.

7. Competence (buman resources). Wikipedia. The Free Encyclopedia website. Retrieved in February 2012 from http:// en.wikipedia.org/wiki/Competence_\%28human_resources\%29, accessed on 05.04.2019, 20.05.

8. . ***, Academia Română, coord. Acad. Vlad. I.V., Strategia de dęvoltare a româniei în următorii 20 de ani, Volumul I, Editura Academiei Române, 2015, pag. 11-30

9. *** Dictionar de sociologie, Larousse de sociologie, 1996, pag. 341.

10. bttps:/ / mnw.edu.ro/formare-continua, accessed on 04.05.2019, 12.15.

11.http:// dialoguriedu.cpedu.ro/wp-content/uploads/2017/08/Document-Pozitie-Profilul-de-competente-alprofesorului.pdf, accessed on 24.04.2019, 13.47.

12.http:/ / www.stiucum.com/ management/ management-educational/Notiuni-introductive-despre-or15245.php, accessed on 24.04.2019, 14.53.

13. bttps:// wmw.scribd.com/document/377993061/Ce-Este-o-Organizatie-Scolara, accessed on 06.04.2019, 19.33. 